\title{
Ballast Water Management: Policy to Sampling - the Orkney Experience \\ David Sawkins ${ }^{\mathrm{a}}$, Jenni Kakkonen ${ }^{\mathrm{b}}$ \\ aHarbour Authority, Orkney, UK; ' $O$ Orkney Islands Council, Orkney, UK.
}

\section{ABSTRACT}

Orkney Islands Council is the Statutory Harbour Authority for Scapa Flow - a $324.5 \mathrm{~km}^{2}$ area of deep water and sheltered anchorage in the Orkney Islands, north of mainland Scotland, with a long history and present use by all types of shipping. This paper will provide a short introduction to the development of the IMO and EU Directive compliant Ballast Water Management Policy for Scapa Flow which was approved by the competent planning authority in December 2013. Scapa Flow is in an environmentally sensitive area, this along with best practice was taken into account when developing the Policy - which includes strict and enforceable requirements on vessels and the Harbour Authority with regards to operations, monitoring and reporting.

Since its approval there have been thirty-three occasions where ballast water discharge into Scapa Flow (by various types of vessels) has been requested. The Policy requires that vessels requesting to discharge ballast water into Scapa Flow must exchange and treat (where a treatment system is fitted) on every visit to Scapa Flow (no exceptions or exemptions allowed). To date thirty-one vessels have carried out exchange and two have carried out exchange and treat - all as per the Policy.

This paper will deal with the setting of an IMO compliant Ballast Water Policy through to practical application by a Statutory Harbour Authority for a period of three years from 2013 to present day - with examples of ship types, amounts, any restrictions imposed, checks and reports made. It will include - with input from the Harbour Authority's Marine Environment Unit lead by Jenni Kakkonen -a review of the positive actions, problems, solutions and overall results obtained so far regarding taking ballast water samples from these vessels, analysing the same and recording of details.

There is a continual review and reporting process with regards to the effectiveness of the Policy to the Orkney Marine Environment Protection Committee (comprising of all the relevant statutory advisors and interested groups). The paper will contain the Harbour Authority's way ahead in order to remain compliant, maintain its knowledge base of new technologies and environmental reports - all with the continued aim of maintaining the environment and commercial sustainability of Scapa Flow as a leading port and harbour.

Keywords: Ballast Water, Policy, IMO, Orkney, Non-native species

\section{Introduction}

The Orkney Islands - a group of approximately 70 islands - lie $16 \mathrm{~km}$ off the north-east tip of Scotland where the North Sea and Atlantic Ocean meet. The total coastline length is approximately $1,052 \mathrm{~km}$ with a land area of approximately $1011 \mathrm{~km}^{2}$.There is a rich tradition of agriculture, seafaring, fishing and all matters to do with the sea, with human life and history spanning in excess of 5000 years. 


\section{The Orkney Environment}

Orkney is well known for its pristine environment both ashore and at sea. This is reflected in a very successful tourism market, with in excess of 220000 visitors per annum - made up of visitors (from all over the world) and from the 145 cruise ships that arrive mainly from April to September.

The maintenance of the pristine environment is vital and important to the people of Orkney for the sustainability of life within the islands. Over the last forty or so years, this has meant that very careful management of the environment has been undertaken.

In the early 1970's the oil industry in the northern North Sea escalated to the extent that large oil companies were looking for shore installations. As a result, an oil terminal on the island of Flotta (on the southern edge of Scapa Flow) was constructed and commenced production in January 1977 - receiving crude oil via pipeline, processing and exporting the product via oil tankers.

At that time, all major projects tended to be engineering led with environmental considerations treated as an afterthought. As a precursor in the application of environmental assessment methodology, Flotta was in the vanguard of advanced innovative planning and design - with all parties involved withdrawing from a confrontational approach to one of being positive participants in improving environmental understanding and mitigating measures. ${ }^{1}$

In addition, the Orkney County Council Act 1974 set Orkney Islands Council as the Statutory Harbour Authority for specific areas. This included (amongst others) the whole of Scapa Flow, being a $324.5 \mathrm{~km}^{2}$ deep water sheltered anchorage with a long history of being used by many vessels, in particular the Royal Navy and commercial shipping.

\section{Ballast Water Management Policy for Scapa Flow}

During 2010 the Harbour Authority concluded that a ballast water policy that had been introduced during the 1980's was out of date and not commercially viable. This, along with the publication (and all be it slow progress towards ratification) of the International Maritime Organization (IMO) Convention for the Control and Management of Ships' Ballast Water and Sediments Convention (BMWC) in 2004 meant that at some stage the Harbour Authority would have to take this into consideration when revising the Policy for Scapa Flow.

In addition to the BWMC, since the 1990's various European Directives were issued which required certain steps to be undertaken in order to ensure designated environmental sites were not affected by developments or policies. These directives are (but not limited to) the Habitats Directive (Council Directive 92/43/EC) and Birds Directive (Council Directive $2009 / 147 / E C)$. This legislation resulted in the designation of many sites in and around Scotland and Orkney as shown in Figures 1 and 2 respectively. 


\section{Figure 1. Regional Areas}
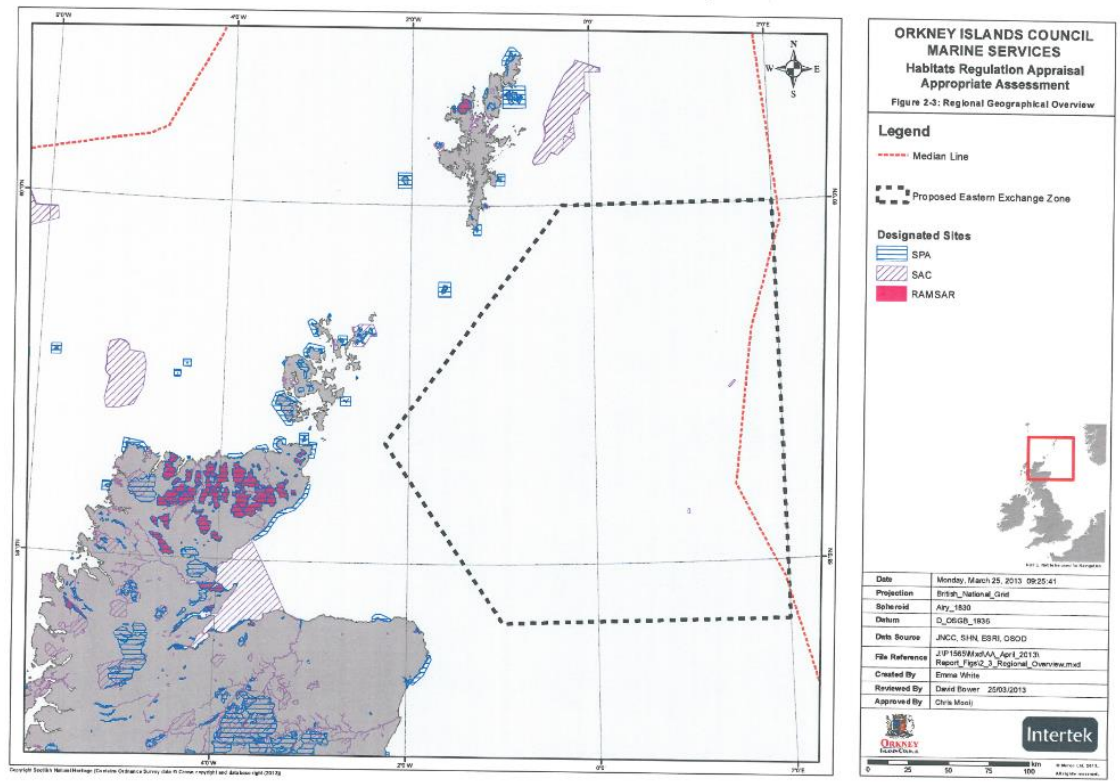

Figure 2. Local Areas
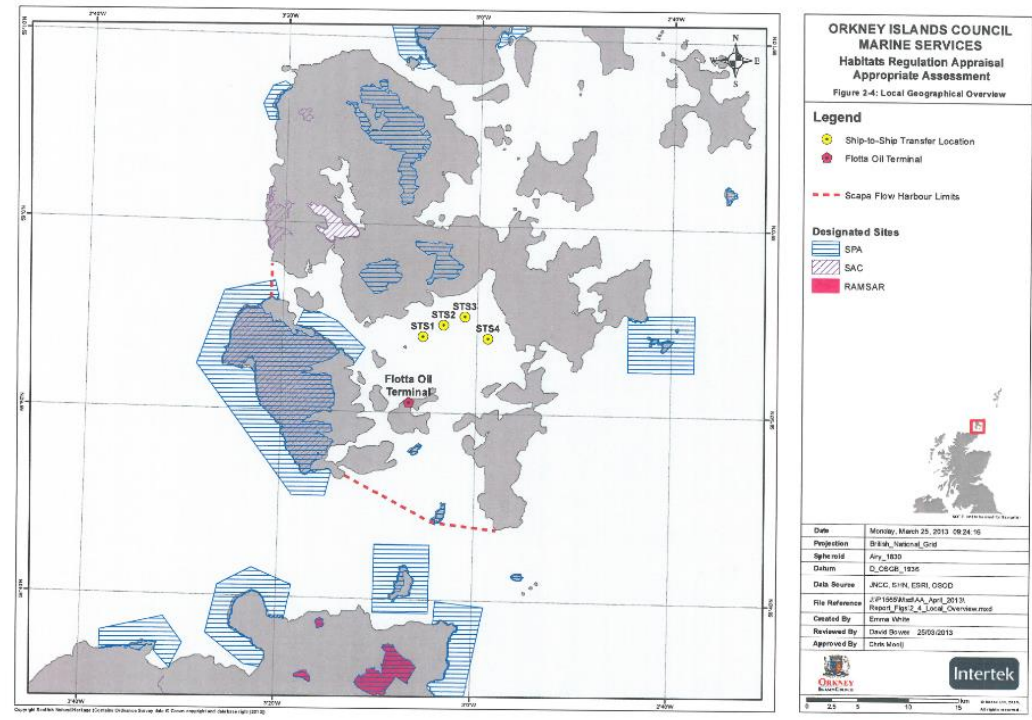

After an initial Strategic Environmental Assessment (SEA) / Environmental Impact Assessment (EIA) in 2010 it became obvious that under the Habitats Regulation Appraisal (HRA) requirements that an Appropriate Assessment (AA) of a revised ballast water policy would be required.

The meshing of IMO and EU requirements into one policy was to prove to be a long and difficult process - in particular meeting the EU requirements of the precautionary principle. From 2011 until the Ballast Water Management Policy for Scapa Flow ${ }^{3}$ was approved by Orkney Islands Council on 10 December 2013 the following was undertaken:- 
- A full mathematical model of tides, currents in the northern North Sea and around the whole of the Orkney Islands was generated

- A full and detailed model of tides, currents, bathymetry for the whole of Scapa Flow was generated.

- Check and revision of the original SEA / EIA documentation.

- HRA / AA process.

- Check and integration of the IMO 2004 Convention into an IMO / EU compliant Ballast Water Management Policy for Scapa Flow.

- Numerous consultation events with local and national bodies, organisations, government advisory bodies, public seminars and with the members of the Orkney Islands Council.

- Baseline study carried out in order to determine what non-native species exist in Scapa Flow - using historical records and the taking of samples at locations as per the Policy.

The approved Policy includes a requirement for the Harbour Authority to carry out a nonnative species monitoring and recording process for Scapa Flow.

The locations of the monitoring points within Scapa Flow and Loch of Stenness (a high level special area of conservation) were decided after consideration of tidal flows and locations of man-made structures in Scapa Flow. It was important to monitor different habitats, for example navigation buoys, pier walls, water column and seabed sediments to ensure a good coverage of the diverse habitats present, along with an imperative not to place objects into Scapa Flow which could act as stepping stones for any non-native species. The methods used in the sampling were rapid assessments, scrape sampling, sediment grab sampling, net sampling and the use of sediment panels. Water temperature and salinity samples were collected at all locations. The harbour baseline survey was carried out in the spring and late summer 2013 and the on-going monitoring programme began in 2014 .

As a result of all these various pieces of work, it was ascertained beyond reasonable scientific doubt, that the Policy for Scapa Flow would have no adverse effect on the integrity of any European Sites.

The approved Policy contains requirements for all vessels over 400 gt (with the exception of those using Flotta Oil Terminal, which has alternative arrangements) wishing to discharge ballast water into Scapa Flow to exchange or exchange and treat (if an approved ballast water treatment system (BWTS) is fitted) before permission is given by the Harbour Authority. Ballast Water exchange (BWE) must be carried out as per the BWMC or in a specified area in the North Sea. The IMO exchange form (Resolution A.868 (20)) or company equivalent is sent to the Harbour Authority before arrival. Part of the assessment by the Harbour Authority on arrival and before permission to discharge is given, and with permission of the Master, the Harbour Authority attends the vessel to check all details pertaining to the BWE, BWTS and vessels Ballast Water Management Plan (BWMP). 


\section{Ballast Water Sampling - On Board}

The majority of vessels using Scapa Flow that wish to discharge ballast water are undertaking ship-to-ship (STS) transfers of crude oil, liquefied natural gas (LNG) or liquefied petroleum gas (LPG) - which are carried out at anchor designated STS positions in Scapa Flow as in Figure 3.

Figure 3. Scapa Flow and STS locations
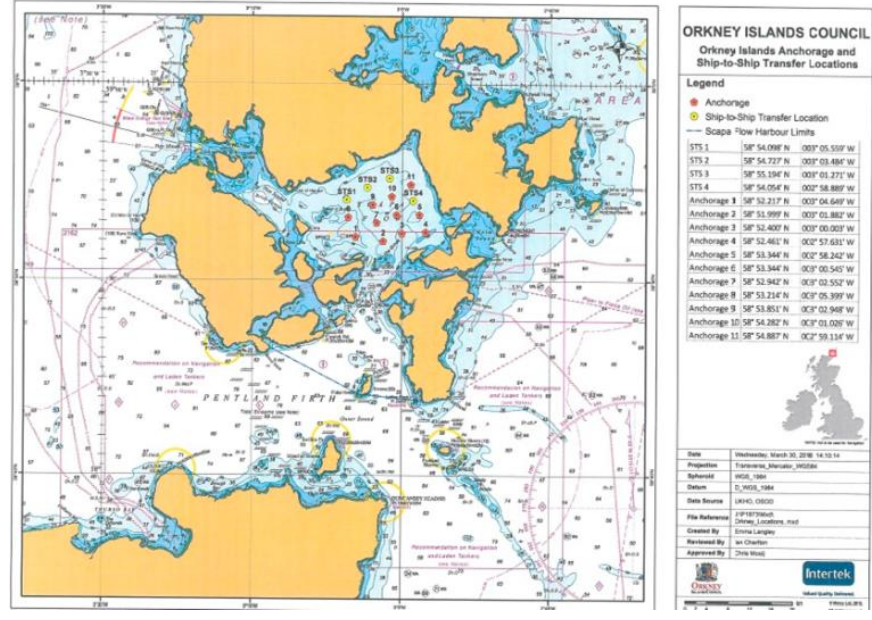

Since 1980 there have been in excess of 250 STS operations in Scapa Flow, which includes 33 STS operations in the period late 2013 to December 2016. Due to operational and ship design characteristics not all of these vessels required to discharge ballast water (amounting to 5 vessels). Therefore since the Policy was approved, there have been 28 vessels visited by the Harbour Authority and ballast water samples taken. All of the 28 vessels undertook BWE to the BWMC standard with two of these fitted with BWTS.

\section{Figure 4. Access to vessels}

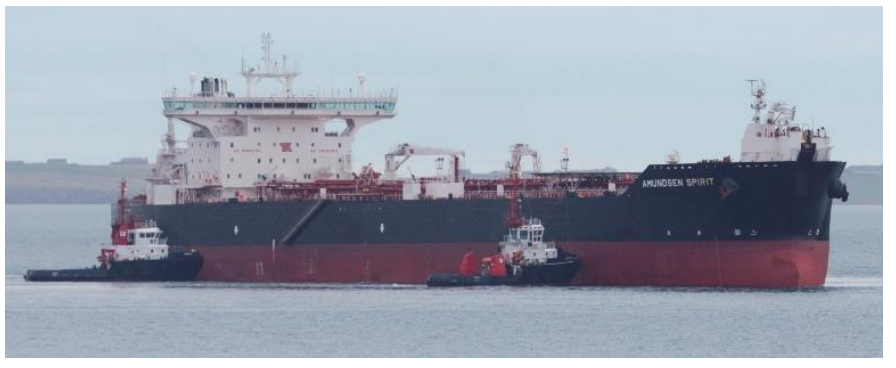

In majority of the cases the ballast water samples were taken directly from the ballast water tanks using the guidance contained within the BWMC with the aim of ensuring that the samples remain scientifically viable throughout the process.

Once taken the samples were stabilised as necessary, they are sent to various accredited testing laboratories, to test for:- 
- Salinity

- Bacteria

- Phytoplankton - both small and large fraction size

- Zooplankton - both small and large fraction size

It should be noted that the sample testing - especially for the phyto and zooplankton samples - were for total counts within the samples ie: not just to the BWMC D-2 standard, but to a much higher standard of enumerating the total abundance of specimens to the lowest taxonomic level possible and preferably to species level in each sample.

So far problems, which have always resulted in solutions, with taking ballast water samples on board have been:-

- Access to the vessel, noting that they have always been at anchor and therefore is via a Harbour Authority pilot boat, are often in a fully ballasted condition and therefore require persons to be able and capable of climbing pilot ladders and accommodation ladders. See figure 4 for an example.

- Sampling equipment on board - getting ballast water sampling equipment, plankton nets, rope, flow and salinity meters and a pump and associated hoses on board a vessel at anchor means a specific loading scenario.

- Specific type of sampling equipment - as the vast majority of samples taken have been from the main deck access hatches on oil tankers, the type of equipment that can be used is limited (ie: very strict health and safety regulations). Therefore deck sampling equipment is kept to an absolute minimum, no electrical instrumentation and any pumps used being air driven.

- Maintaining scientific viability of samples at all times - taking very accurate samples without the possibility of contamination on the open deck of an oil tanker in the middle of the night in Orkney results in some interesting, but not impossible, problems to overcome.

- Once the samples are taken they need to be couriered to testing laboratories - in Orkney there are no suitable laboratories for carrying out the testing required. In addition the specification for testing the bacterial samples is that they must be at the laboratory within 24 hours from the time of sampling. The nearest suitable laboratory is in Aberdeen - an hour flight away and at most three flights a day between 0700 and 1600 . This can cause problems with samples taken at night and weekends (different flights).

- Training of the sampling team - this must be undertaken in order that scientific viability of the samples is maintained under difficult conditions. Virtually every vessel has a different configuration for ballast water access hatches, therefore until actually on board the sample team do not know for certain which methods can be used - they must be versatile but understand the reasoning behind the methods for taking samples. 


\section{Conclusion}

With three years of practical experience and having spent the previous three years setting an IMO / EU compliant Policy the Orkney Harbour Authority has developed methods that will go a long way in reducing the spread of non- native species by shipping. This is an on-going piece of work with the annual monitoring and reporting of results as per the Policy, the continuing checking of vessels, the initial arrival of vessels with treatment systems and the implications this will have. As of the end of 2016 there have been two vessels visiting Scapa Flow with BWTS fitted - which from initial tests indicate that the treatment systems do have a positive effect in reducing viable organisms, but as yet it cannot be said with any certainty that this is to the D-2 standard.

In conclusion the following may be drawn out of experience thus far:-

- Sampling methods need to be adapted almost at case-by-case basis

- Sampling equipment needs to be versatile and the sampling team need to understand how to use and adapt methods

- Salinity checks on-board vessels are a good quick method to give guidance if ballast water exchange has been carried out

- Access to vessels at anchor, an issue both for sampling team and equipment

- On-shore support for sampling team at departure and especially at arrival vital to ensure that the samples have been collected correctly

- So far there have been no problems from the vessels' crews whilst carrying out checks and taking samples.

The Policy, monitoring, reporting and vessel sampling processes will always be classed as "work in progress" as research, methods and instrumentation are developed - it does not end in 2016.

\section{References}

Flotta Oil Handling Terminal, Scapa Flow, Orkney, Case Studies 2016. Respsol Sinopec Resources UK Ltd and International Centre for Oil and the Environment. October 2016. http://www.orkneyharbours.com/pdfs/bwm/Ballast\%20Water\%20Management\%20Policy\%20 for\%20Scapa\%20Flow\%20April\%202014.pdf 